\title{
Cognitive Factors and its Impact on Job Satisfaction- A Study on Selected Information Technology Enabled Service Companies in Bengaluru
}

\author{
Anthony Samson ${ }^{1 *}$ and K. Nagendra Babu ${ }^{2}$ \\ ${ }^{1}$ Research Scholar, Department of Commerce, University of Mysore, Mysore, India \\ ${ }^{2}$ Associate Professor, Department of Commerce, University of Mysore, Mysore, India
}

\begin{abstract}
Everybody agrees that, the most valuable asset of any business for that matter it is the human beings who work there. Satisfied employees become productive assets of the company and they play a very important role in the overall development of the company. In order to get the employees involved, both physically as well as emotionally companies must assure that they satisfy the physical as well as emotion needs of the employees. Employees' job satisfaction plays a vital role in the long run. This article tries to find out the role of cognitive factors on job satisfaction. Keeping job satisfaction as dependent variable and cognitive factors as an independent variable the study has been undertaken. For the purpose of the study the data has been collected from 1000 employees working in 10 different ITeS companies in Bengaluru. Respondents were selected through stratified random technique. The result of the study has shown that cognitive factors significantly influence job satisfaction among the employees of ITeS companies in Bengaluru.
\end{abstract}

Keywords: Job satisfaction, Cognitive, performance, ITeS and Employees

\section{Introduction}

\subsection{Job Satisfaction and Cognitive Factors}

The relationship between job satisfaction and cognitive factors is very strong. Job satisfaction stands on two important aspects they are, affective and cognitive factors. The present study concentrates only on cognitive factors which are related to autonomy, liberty and freedom in decision making given to the employees by the employer. Cognitions are often characterized as the content of thoughts or beliefs about an attitude object or statement of fact in question, usually in comparison to a standard or expectation (Bagozzi, 1978; Campbell, 1976; Crites et al., 1994; Organ and Near, 1985; Weiss, 2002b; Weiss and Cropanzano, 1996).

\section{Review of Literature on Job Satisfaction}

Hoppock (1935) was of the view that job satisfaction is any combination of psychological, physiological and environmental circumstances, which cause a person truthfully, satisfied with his/her job.

Locke (1976) defined job satisfaction as "a pleasurable or positive emotional state resulting from the appraisal of one's job or job experience". 
Feldman and Arnold (1983) have defined job satisfaction as, "Job satisfaction will be defined as the amount of overall positive affect (or feelings) that individuals have towards their jobs".

Abraham's (2012) study was conducted to examine the effect of job satisfaction on employee engagement among 30 employees of a private insurance company at Cochin. Results showed that Job satisfaction and Employee engagement are related (correlation). Regression results highlighted factors, such as, nature of the job, superior's recognition to one's work, team spirit, cooperation between departments, comparative benefits, equal and proper administration of company policies contributed to a moderate state of employee engagement.

\section{Cognitive Factors}

Hackman \& Oldham, (1976) have opined that Job Autonomy is a degree to which the job provides substantial freedom, independence and discretion to the employee in determining the procedures to be used in carrying it. Job with high degree of autonomy creates a sense of responsibility and greater job satisfaction in the employees

Bagozzi, (1978) Campbell, (1976) state that, Cognitions are often characterized as the content of thoughts or beliefs about an attitude object or statement of fact in question, usually in comparison to a standard or expectation. For example, if an employee expects a certain level of autonomy in the way he works and is being micromanaged, the discrepancy between expected and perceived autonomy may lead to thoughts of dissatisfaction

Hossain (2000) found that bank executives were significantly more satisfied in their jobs than non-executives. Higher level employees were more satisfied because they enjoyed more opportunity to satisfy their ego needs, high status, higher payment and self - direction than lower level employees.

De'Carlo \& Agarwal (1999) examined the effects of managerial behavior (i.e., initiation of structure and consideration) and job autonomy on industrial salesperson's job satisfaction. The study also investigated the generalizability of the theoretical model developed for U.S. salespersons to salespersons in Australia and India. The study findings suggested that perceived job autonomy was an important antecedent to job satisfaction among salespersons from all three countries. Surprisingly, little differences were observed in the impact of managerial initiation of structure and consideration on job satisfaction among the sales personnel from three countries. The investigator, therefore, feels that effect of job autonomy vary according to the hierarchical levels of employees.

\section{Need for the Study}

Past two decades the ITeS sector has seen tremendous development in terms of growth, related to profitability and also turnover. The assumption which is commonly laid is that profitable business will have satisfied employees in all the aspect. This paper tries to find out which factors connected to employee satisfaction are really met by the employers.

\section{Problem Statement}

ITeS business is people business. The people run the business mainly using technology in this industry. Job satisfaction among the employees is a must and also the degree of freedom in decision making is essential at times. The hi-tech industry which runs on technology assures autonomy, liberty, freedom and also overall job satisfaction among the employees in ITeS companies in Bengaluru.

\section{Objectives of the Study}

- To know the level of job satisfaction among the employees of different ITeS companies.

- To know the relationship between job satisfaction and the cognitive factors among the employees of different ITeS companies.

\section{Scope of the Study}

Various studies have been undertaken to find out the relationship with job satisfaction and other factors, as such, related to IT industry. But when it comes to ITeS industries related to job satisfaction with cognitive 
factors the work is very limited. The study tries to examine the relationship between job satisfaction and cognitive factors. This study is limited to $10 \mathrm{ITeS}$ companies in Bengaluru. For the purpose of the study, various demographic variables, such as Age, Gender, Education, Income and Experience were taken into consideration. Companies taken for the study were Infosys, Wipro, Syntel, SAP, Zenith, Unisys, Oracle, Genesis, HCL and Siemens.

\section{Research Methodology}

This research is exploratory in nature. In this study, the researcher has tried to find out the level of job satisfaction and the influence of cognitive factors on job satisfaction. Companies having more than 1000 employees have been selected for the study. 1000 respondents were selected from 10 different ITeS companies functioning in Bengaluru. Individual Mean, Median, Standard Deviation was calculated. Kruskal Wallis Test was conducted to test the reliability with-in the component. Regression analysis was undertaken to evaluate the impact factors on each other. Factor analysis was undertaken to find out impacting component within the construct i.e. job satisfaction and cognitive factors. Cronbach alpha for job satisfaction came to .823 and cognitive factors to.829. Likert's five point scale was used to measure job satisfaction and cognitive factors.

Table 1. KMO and Bartlett's test for job satisfaction

\begin{tabular}{lc}
\hline Kaiser-Meyer-0lkin Measure of Sampling & \\
\hline Adequacy. & .817 \\
Approx. Chi-Square & 10575.246 \\
Bartlett's Test of Sphericity & 0 \\
Df & 66 \\
Sig. & .000 \\
\hline
\end{tabular}

\section{Hypothesis 1}

$\mathbf{H}_{0}$ : "JobSatisfaction among the employees of different ITeS companies differs significantly".

$\mathbf{H}_{1}$ : "Job Satisfaction among the employees of different ITeS companies doesn't differ significantly".

Twelve questions were asked to the respondents related to job satisfaction. The table 1 annexure shows $\mathrm{KMO}=.817(>.5)$ shows that there is sampling adequacy and also Bartlett's Test of Sphericity is significant as $(\mathrm{p}=.000<.01)$.

From the table 3 (annexature) it is clear that overall employees agree that they are not satisfied with their jobs performed in their respective companies with Mean and Standard Deviation 2.52 \pm .74 (Mean Value $<3) \mathrm{p}=.758>.01 \mathrm{NS}$.

Table 3. Percentages of satisfied employees

\begin{tabular}{cccc}
\hline $\begin{array}{c}\text { Type of } \\
\text { companies }\end{array}$ & Not satisfied & Satisfied & Total \\
\hline \multirow{2}{*}{ Type 1 } & 195 & 98 & 293 \\
& $66.8 \%$ & $33.2 \%$ & $100.0 \%$ \\
Type 2 & 253 & 154 & 407 \\
& $62.0 \%$ & $38.0 \%$ & $100.0 \%$ \\
Type 3 & 263 & 37 & 300 \\
& $87.7 \%$ & $12.3 \%$ & $100.0 \%$ \\
Total & 711 & 28 & 1000 \\
& $71.1 \%$ & $28.9 \%$ & 100.0 \\
\hline
\end{tabular}

Majority of employees to the extent of $71.1 \%$ are not satisfied. To the extent of $28.9 \%$ employees are satisfied. In case of type 1 companies to the extent of $66.8 \%$ employees are not satisfied whereas, to extent of $32.2 \%$ are satisfied. Type 2 companies have $62 \%$ dis-satisfied employees and $38 \%$ of employees are satisfied. Type 3

Table 2. Overall job satisfaction with Mean, SD, Median and KWT

\begin{tabular}{cccccccc}
\hline $\begin{array}{c}\text { Type of } \\
\text { companies }\end{array}$ & $\mathrm{N}$ & Mean & Std. Deviation & Median & $\begin{array}{c}\text { Kruskal- Wallis Test } \\
\text { x 2 value }\end{array}$ & d.f & p value \\
\hline Type 1 & 289 & 2.56 & .84 & 2.00 & .095 & 1 & \\
Type 2 & 407 & 2.62 & .76 & 2.42 & & & \\
Type 3 & 300 & 2.34 & .57 & 2.25 & & & \\
Total & 996 & 2.52 & .74 & 2.25 & & & .758 NS \\
\hline
\end{tabular}


companies has highest percentage of dis-satisfied employees i.e. $87.7 \%$ and $12.3 \%$ of employees were satisfied.

Table 4. Chi-square test for satisfied employees

\begin{tabular}{cccc}
\hline$X^{2}$ & df & $p$ & \\
\hline 59.097 & 2 & .000 & HS \\
\hline
\end{tabular}

The above test shows that the level of Job Satisfaction vary significantly across the companies as $\mathrm{p}=.000<.01$. So, we can conclude that in case of type 3 companies there are more dissatisfied employees (87.7\%) when compared to type 1 and type 2 companies.

\section{Extraction Method}

\subsection{Principal Component Analysis}

Factor analysis has extracted 3 important components related to Job Satisfaction, stating a total variation of $76.919 \%$. Component 1 is nothing but the primary reasons for job dissatisfaction (6 reasons) showing variance of $27.819 \%$. Component 2 i.e. secondary reasons with (3 factors) showing $24.589 \%$ of variance. Third component ( 3 reasons) shows $24.511 \%$ of variance. Thus, it is clear from the table 4 (annexature) that the employees of various companies vary significantly toward job satisfaction. The chi-square test shows that employees across the companies vary significantly as $\mathrm{p}=.000<0.01$. Hence Null hypothesis is accepted.

\section{Hypothesis 2}

$\mathbf{H}_{0}$ : "Cognitive factors have a significant influence on job satisfaction among the employees of ITeS companies".

$\mathbf{H}_{1}$ : "Cognitive factors do not have a significant influence on job satisfaction among the employees of ITeS companies".

Table 6. Correlation for cognitive v/s job satisfaction

\begin{tabular}{cccc}
\hline Basis & Variables & Pearson Correlation & $\mathrm{p}$ \\
\hline Cognitive & Satisfaction & $.819^{\star \star}$ & .000 \\
& cognitive & 1 & \\
\hline
\end{tabular}

${ }^{* *}$ Correlation is s significant at the 0.01 level

To evaluate correlation between cognitive factors and job satisfaction, Karl Pearson test was conducted and the result was obtained that $\mathrm{r}=.819, \mathrm{p}=.000<.01$. Hence, it can be concluded that there is a relationship between Cognitive factors and job satisfaction among the employees of various ITeS companies.

Table 7. Regression for cognitive v/s job satisfaction

\begin{tabular}{ccccc}
\hline Model & $\mathrm{R}$ & $\mathrm{R}$ Square & Adjusted R Square & Std. Error of the Estimate \\
\hline 1 & $.852^{\mathrm{a}}$ & .726 & .723 & .39164 \\
\hline
\end{tabular}

a. Predictors: (Constant), Employer encourages to pursue higher education, Cordial atmosphere to

Table 5. Total variance related to job satisfaction

\begin{tabular}{|c|c|c|c|c|c|c|c|c|c|}
\hline \multirow{2}{*}{ Component } & \multicolumn{3}{|c|}{ Initial Eigenvalues } & \multicolumn{3}{|c|}{ Extraction Sums of Squared Loadings } & \multicolumn{3}{|c|}{ Rotation Sums of Squared Loadings } \\
\hline & Total & $\%$ of Variance & Cumulative $\%$ & Total & $\%$ of Variance & Cumulative $\%$ & Total & $\%$ of Variance & Cumulative $\%$ \\
\hline 1 & 6.535 & 54.462 & 54.462 & 6.535 & 54.462 & 54.462 & 3.338 & 27.819 & 27.819 \\
\hline 2 & 1.484 & 12.364 & 66.826 & 1.484 & 12.364 & 66.826 & 2.951 & 24.589 & 52.408 \\
\hline 3 & 1.211 & 10.093 & 76.919 & 1.211 & 10.093 & 76.919 & 2.941 & 24.511 & 76.919 \\
\hline 4 & .708 & 5.896 & 82.815 & & & & & & \\
\hline 5 & .559 & 4.656 & 87.471 & & & & & & \\
\hline 6 & .534 & 4.452 & 91.923 & & & & & & \\
\hline 7 & .262 & 2.185 & 94.108 & & & & & & \\
\hline 8 & .234 & 1.954 & 96.061 & & & & & & \\
\hline 9 & .180 & 1.499 & 97.560 & & & & & & \\
\hline 10 & .122 & 1.019 & 98.579 & & & & & & \\
\hline 11 & .096 & .797 & 99.376 & & & & & & \\
\hline 12 & .075 & .624 & 100.000 & & & & & & \\
\hline
\end{tabular}


Table 8. Anova for cognitive v/s job satisfaction

\begin{tabular}{ccccccc}
\hline \multirow{2}{*}{ Model } & & $\begin{array}{c}\text { Sum of } \\
\text { Squares }\end{array}$ & df & $\begin{array}{c}\text { Mean } \\
\text { Square }\end{array}$ & F & \multirow{2}{*}{ Sig. } \\
\hline \multirow{2}{*}{1} & Regression & 401.341 & 11 & 36.486 & 237.876 & $.000^{\mathrm{a}}$ \\
& Residual & 151.387 & 984 & .153 & & \\
\hline & Total & 552.728 & 995 & & & \\
\hline
\end{tabular}

Table 9. Coefficients for cognitive v/s job satisfaction

\begin{tabular}{|c|c|c|c|c|c|c|}
\hline \multirow{2}{*}{ Model } & & \multicolumn{2}{|c|}{$\begin{array}{l}\text { Unstandardized } \\
\text { Coefficients }\end{array}$} & \multirow{2}{*}{$\begin{array}{c}\text { Standardized } \\
\text { Coefficients } \\
\text { Beta }\end{array}$} & \multirow{2}{*}{$\mathrm{t}$} & \multirow{2}{*}{ Sig. } \\
\hline & & B & $\begin{array}{l}\text { Std. } \\
\text { Error }\end{array}$ & & & \\
\hline \multirow[t]{17}{*}{1} & (Constant) & .342 & .062 & & 5.553 & .000 \\
\hline & $\begin{array}{l}\text { Employer } \\
\text { organises }\end{array}$ & & & & & \\
\hline & $\begin{array}{c}\text { Empowerment } \\
\text { programme }\end{array}$ & .020 & .025 & .024 & .784 & .434 \\
\hline & $\begin{array}{c}\text { Employer } \\
\text { delegates } \\
\text { enough } \\
\text { authority }\end{array}$ & .114 & .030 & .152 & 3.850 & .000 \\
\hline & $\begin{array}{l}\text { Liberty of } \\
\text { doing duty } \\
\text { Cordial }\end{array}$ & .080 & .021 & .116 & 3.851 & .000 \\
\hline & atmosphere to & .064 & .024 & .079 & 2.664 & .008 \\
\hline & Career & & & & & \\
\hline & $\begin{array}{l}\text { development } \\
\text { programme is } \\
\text { good }\end{array}$ & .326 & .023 & .440 & 14.446 & .000 \\
\hline & $\begin{array}{l}\text { Benefits } \\
\text { paid aim at }\end{array}$ & -.157 & .027 & -.208 & -5.858 & .000 \\
\hline & $\begin{array}{l}\text { best talent } \\
\text { team work at }\end{array}$ & & & & & \\
\hline & $\begin{array}{l}\text { middle level is } \\
\text { pleasure }\end{array}$ & .076 & .016 & .117 & 4.672 & .000 \\
\hline & $\begin{array}{c}\text { Colleagues } \\
\text { respect my } \\
\text { decisions }\end{array}$ & .195 & .029 & .291 & 6.728 & .000 \\
\hline & $\begin{array}{l}\text { Companies } \\
\text { policies are in } \\
\text { par with the } \\
\text { industry }\end{array}$ & -.137 & .034 & -.177 & -4.013 & .000 \\
\hline & Employer & & & & & \\
\hline & $\begin{array}{l}\text { encourages } \\
\text { Know ledge }\end{array}$ & .076 & .021 & .104 & 3.603 & .000 \\
\hline & & & & & & \\
\hline & $\begin{array}{c}\text { encourages to } \\
\text { pursue higher } \\
\text { education }\end{array}$ & . 183 & .019 & .229 & 9.768 & .000 \\
\hline
\end{tabular}

perform best, Employer organisation empowerment program, Liberty of doing duty, team work at middle level is pleasure, Employer encourages Knowledge enhancement, Career development programme is good, Colleagues respect my decisions, benefits paid aim at retaining the best talent, Employer delegates enough authority, Companies policies are at par with the industry. a. Predictors: (constant), same as the above i.e. regression table 7

b. Dependent Variable: Satisfaction

Multiple regression and Anova test was performed and the results shows that among 11 cognitive factors except employer organises empowerment programmes other 10 factors have significant impact on Job satisfaction. All these factors have $72.3 \%$ (Adjusted $\mathrm{R}^{2}$ ) impact on Job satisfaction.

\section{a. Dependent Variable: Satisfaction.}

The coefficient value clearly shows that, the employer organizes empowerment programmes have very less effect ( $\mathrm{p}=.434 \mathrm{NS}$ ) where the beta value is.024. Remaining 10 factors have a significant impact on job satisfaction with higher beta value and also $p=.000<.01$

\section{CHART SHOWLNG THE BETA VALUES COGNATVE AND JOB SATISFACTION}

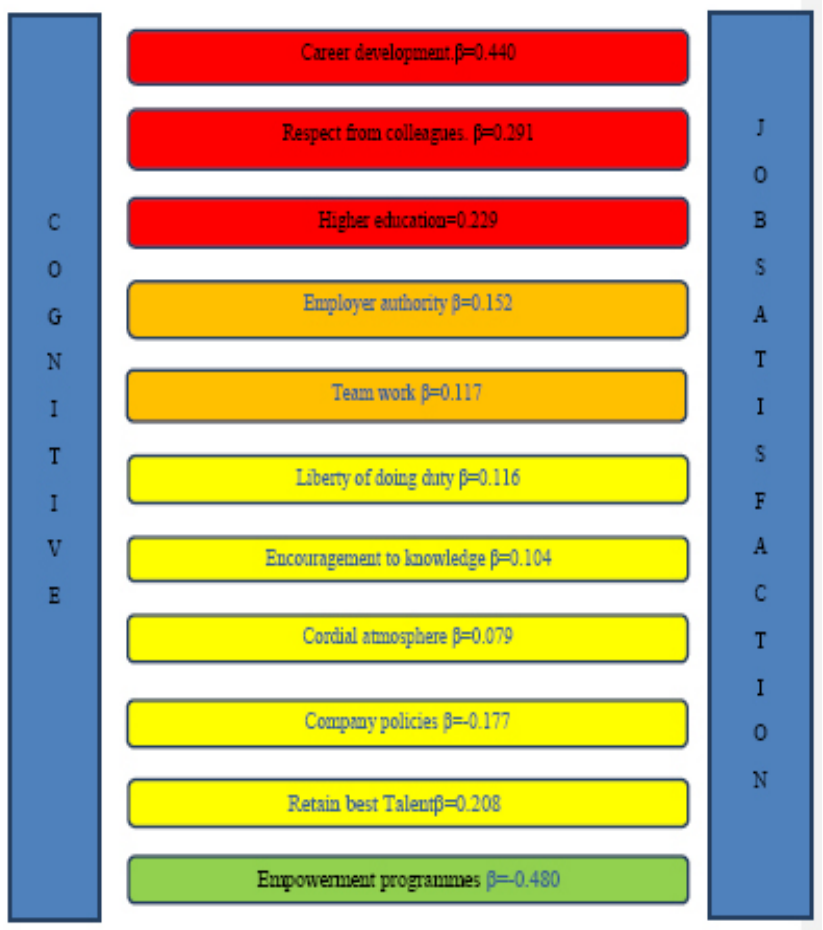

To conclude, one can say that there is an impact of Cognitive factors on job satisfaction among employees of various ITeS employees as the adjusted $\mathrm{R}^{2}=.723$. indicates That is to the extent of $72.3 \%$ of employees agree that there is an impact of Cognitive factors on job satisfaction and thus, Null hypothesis is accepted. 


\section{Findings}

- $71 \%$ of the employees said that they were not satisfied with their present job. In case of type 3 companies nearly $88 \%$ of respondents were dissatisfied.

- The employees have said that they were not paid according to qualification.

- $77 \%$ variation was present as per factor analysis, reasons being primary, secondary and tertiary.

- The correlation test shows that cognitive and job satisfactions were significantly related.

- The regression analysis has shown that the adjusted $\mathrm{R}^{2}$ has an impact to the extent of .723 i.e., cognitive factors have an impact on job satisfaction to the extent $72.3 \%$.

- The Anova test has proven that regression test is significant as $\mathrm{p}=.000<.01$.

- The coefficient of regression has revealed that out of 11 question asked, 1 question was found not significant as ( $\mathrm{p}=.434 \mathrm{NS})$.

- The chart shows the impact on each other i.e. cognitive on job satisfaction. The beta values signifies the impact higher the beta value more will be the impact.

\section{Suggestions}

- All the companies must try to compensate their employees as per the standard set by the industry.

- Compensation must be paid on certain criteria.

- Reasons for dis-satisfaction must be dealt with promptness by the employer.

- The ITeS industry stands on autonomy and liberty. But the results have shown that to the extent of $72.3 \%$ of respondents were not happy with cognitive factors.

- Cognitive factors have a greater impact on job satisfaction therefore the management must deal cautiously with this factor.

\section{Conclusion}

The important factor of production in any industry for that matter, without doubt, is the Human resource. In fact, the relevance of human resource is much higher in ITeS industry, as it human-oriented and not capital-oriented. The big challenge for the modern employer is to see that who can be obtained best among the present staff. The question is how the employer can keep his employees satisfied time and again. Satisfaction is a perception, and therefore, it changes from person to person; understanding their needs and formulation of the policies is the biggest challenge for the ITeS employer's.

Job satisfaction contains two important factors, namely, affective and cognitive. Affective is related to emotions involved in job place whereas, Cognitive factors are related to autonomy at work place. Usually, the people oriented business that is ITeS demand more of autonomy at their work place and they give less importance to emotions. The technically qualified employees demand more of liberty and autonomy at the work place, and if they feel that they have been are deprived of this it results in absenteeism and may lead to turnover. Therefore, the ITeS companies must give due importance to Cognitive factors related to job satisfaction.

\section{References}

Adler, N. J. (1991). International dimensions of organizational behavior. Boston: PWS-Kent Publishing Company. Available from: https://doi.org/10.1002/ job.4030120508

Bagozzi, R. P. (1978). The construct validity of the affective, behavioural, and cognitive components of attitude by analysis of covariance structures. Multivariate Behavioural Research, 13, 9-31. PMid:26758480. Available from: https://doi.org/10.1207/s15327906mbr1301_2

DeCarlo Thomas, E. \& Agarwal S. (1999). Influence of managerial behaviors and job autonomy on job satisfaction of industrial salespersons. Industrial Marketing Management. 28, 51-62. Available from: https://doi. org/10.1016/S0019-8501(98)00022-4

Dr. Susan Abrham is Associate Professor, SCMS School of Technology and Management, Kottayam. susanabraham@scmsgroup.org

Feldman D. C, Hugh J. (1983). Arnold McGraw-Hill, Business \& Economics.

Hackman, J. R \& Oldham, G. R. (1976). Motivation through the design of work. Organizational Behaviour and Human Performance, 16: 250-279. Available from: https://doi. org/10.1016/0030-5073(76)90016-7 
Hoppock, R. (1937). Job satisfaction of psychologists. Strategic report on IT/ITeS industry; 2015-16.

Journal of Applied Psychology, 21(3), 300-303. Available from: https://doi.org/10.1037/h0057579

\section{Internet sources}

Locke, E. A. (1976). The nature and causes of job satisfaction. in dunnette, M. D. Handbook of Industrial and Organizational Psychology. 1st ed. Chicago, Il: Rand McNally. p. 1297-1349.

Available from: http://business.outlookindia.com/pdf/ DeloitteIndiaIT/ITeSindustry.pdf

Available from: http://www.business-and-management.org/ download.php?file=2009/4_2--17-34-Vlachos.pdf 
